\title{
Morphological and Anatomical Diversity Study on three Species of Amaranthus namely; A. hybridus L., A. viridis L. and A.spinosus L. from Rivers State, Nigeria
}

\author{
OZIMEDE, CO; OBUTE, GC; NYANANYO, BL
}

\author{
Department of Plant Science and Biotechnology, University of Port Harcourt, Choba, Port Harcourt, Rivers State, Nigeria \\ *Corresponding Author Email: ozimedechristian@yahoo.com; Other authors Email: gordian.obute@uniport.edu.ng, \\ bionyananyo@yahoo.com
}

\begin{abstract}
A study of morphological and anatomical diversity on three species of Amaranthus in the Amaranthaceae family namely; A. hybridus L., A.viridis L. and A. spinosus L. from the three senatorial district of Rivers state namely; Rivers East (upland), Rivers South East (upland) and Rivers West (coastal region) was studied to examine the diversity that exist even among similar species from different regions. Result obtained from this research showed high rate of diversity. Examination of the tran-sections of blades revealed uni-seriate epidermis, ground tissue with angular collenchyma and slender parenchyma. The vascular bundles shape had only crescent as the shape pattern. The midrib shape in cross section has three patterns in which arc, rounded and crescent bundle occurs. The examination of the petioles exhibits new and varied characters for A. viridis such as petiole shape (cross section), vascular bundles (shape, number, arrangement). While the resulted characters from the observation of the stem structure showed less variation. 52 quantitative and qualitative characters were achieved from morphological and anatomical characters and applied for construction of a dendogram using the Paleontological statistics (PAST) software which showed variation even among similar species from different senatorial district.
\end{abstract}

\section{DOI: https://dx.doi.org/10.4314/jasem.v23i10.17}

Copyright: Copyright (C) 2019 Ozimede et al. This is an open access article distributed under the Creative Commons Attribution License (CCL), which permits unrestricted use, distribution, and reproduction in any medium, provided the original work is properly cited.

Dates: Received: 02 August 2019; Revised: 22 October 2019; 27 October 2019

Keywords: Amaranthus, Morphology, Anatomy, Diversity

Amaranthaceae (pigweed family) is an extensively recognized plant family comprising of annual or perennial herbs (Blunden et al., 1999). Species are primarily found worldwide especially in the tropic and sub-tropical regions. Several varieties are cultivated as ornamentals, vegetable or for grains (Flora of America, 2015), some are weeds (Brenner et al., 2000). The majority of the species in Amaranthaceae family are annual or perennial plants, just few are trees, vine or shrubs. Amaranthus, jointly recognized as amaranth, is a diverse genus of annual or short-cycled crops. Most of the Amaranthus species are annual weeds (pigweed) (Bensch, 2003). Amaranthus genus consists of 70 species with inflorescences stretching from red, purple, through green and red to gold (Mosyakin and Robertson, 2003). Many species possess thickened nodes. Members also have an anomalous secondary growth wood of the perennial stem, normal secondary growth is observed only in the sub-family Poly-cnemoideae leaves can be alternate, opposite, simple or entire, sometimes monoecious while at times dioecious ((Stevens, 2001). Their major regions of distributions are Africa, Australia, China, Italy, Greece, India, Nepal and America (Stallknecht and SchulzSchaeffer, 1993). Amaranthus species express high plasticity to environmental changes, and ensure their fitness by profuse seeds production. Amaranths species also show remarkable diversity linked to their extensive adaptability to diverse eco-geographic situations (Lee et al., 2008). Therefore the objective of this paper is to present the detailed morphological and anatomical characters that will be used to show the rate of diversity among selected species of Amaranthus from Rivers state.

\section{MATERIALS AND METHOD}

Collection and identification of plant materials: Matured plants of the three species from Amaranthus genus found in Rivers State; Amaranthus spinosus, Amaranthus viridis and Amaranthus hybridus were collected each from diverse ecological regions from three senatorial district of Rivers State namely; Obio/akpor local government area in Rivers east, Ahoada west local government area in Rivers west and Oyigbo local government area in Rivers south east senatorial district respectively. Just healthy and fresh parts were obtained. Three independent plants per eco geographical region were gathered from nine plants. The various conditions like land form, Altitude, Longitude, Latitude and Soil types from the sites were taken. Other pieces of information taken includes site 
of collection, collection number, date and name of collector. Identified pressed plant samples were deposited at the UPH Herbarium and also taken to the Forestry herbarium in Ibadan an internationally recognized herbarium for authentication and generation of herbarium number. The voucher samples were placed at the herbarium of the UPH Rivers State. Further lab investigation like anatomy and morphology studies were executed at the UPH Taxonomy and Biosystematics laboratory while molecular analyses were done at the Centre for Biofuel Research in Rivers State and International institute for Tropical Agriculture (IITA) in Ibadan.

Morphological studies: Examinations on the features of Amaranthus which are of taxonomic interest were performed in matured living plant samples. References were also made to several books and Floras including Floras of West tropical Africa (Hutchinson and Dalziel, 1954), useful Plants of West Africa (Burkill, 1985). Quantitative features studied were made possible by the aid of meter-rule and measuring tape. The qualitative and quantitative vegetative features studied include; type, apex, base, margin, shape, width and leaf length, others include petiole length, presence of spines, phyllotaxy and venation of leaf. Also photographs of relevant morphological features were taken.

Anatomical studies: This study further assessed the taxonomic worth of petiole in addition to stem characters in the selected Amaranths as an added line of evidence to a better classification. The Stem, petiole and the midrib anatomy will all be studied for taxonomical characters. About 2-6mm of the Stem, petiole and midrib sections of the plant samples studied were obtained and immediately fixed in FAA (Formalin, Alcohol and Acetic Acid) in the ratio of 1:3:1 for 24 hours according to Johasen (1940). Samples were later transferred into (30, 50 and 70\%) alcohol for three hours respectively and then into absolute alcohol for 24 hours. These dehydrated samples were infiltrated with wax by passing via diverse concentrations of alcohol and chloroform $(3: 1$, 1: 1, 1:3), as chloroform slowly substituted the alcohol. The schedule of paraffin method described by Johansen (1940) was followed, before thin sections were made using sharp razor blade, Photomicrographs were taken using XSZ-N107 Microscope with (MA88-900) camera.

Numerical analysis of morphological and anatomical characters: Taxonomic characters obtained from the morphological and anatomical investigations of (3) species of the Amaranthus genus studied from three senatorial district of Rivers State amounting to nine species in total were grouped by cluster analysis using the single linkage method based on similarity matrix of Euclidean distances of quantitative and qualitative characters. This statistical analysis was done via Paleontological statistics (PAST) software.

\section{RESULTS AND DISCUSSIONS}

Morphological description: Important Morphological differences and similarities observed in the nine species studied are summarized in table 2. While the pictures of the nine species studied showing distinguishing features are presented in Plates $1 \mathrm{a}-1 \mathrm{c}$.

\section{ANATOMY: Midrib}
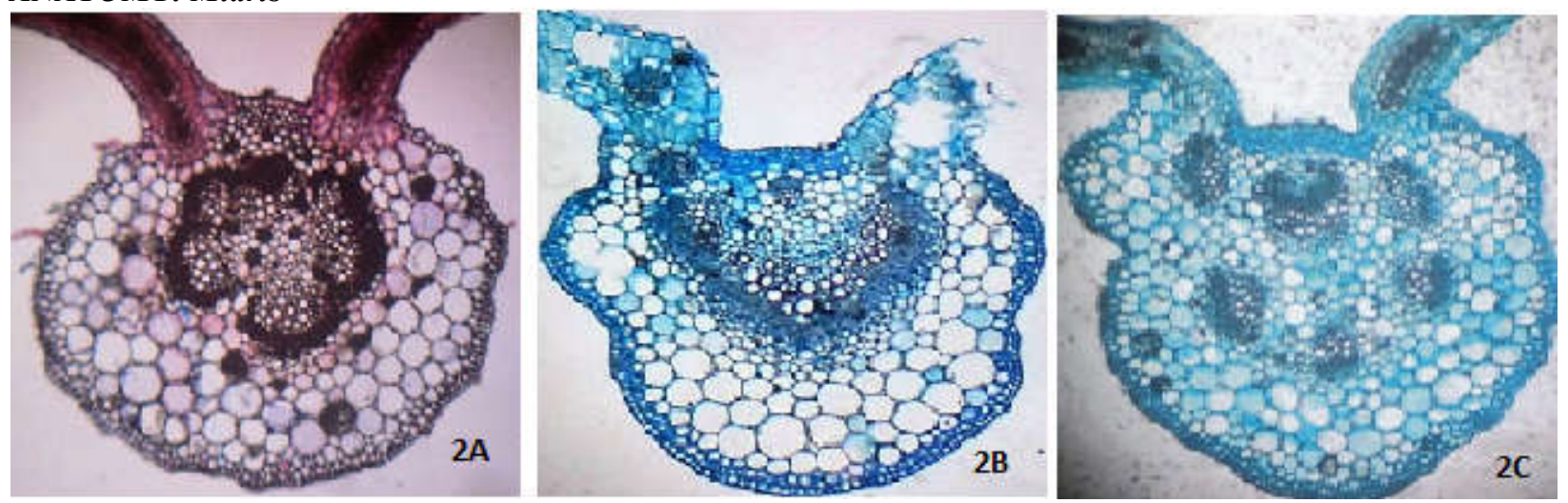

Plate 2a-2c: Transverse section (TS) of the midrib of the Amaranthus species studied showing uniseriate epidermis, presence of sand crystals, small intercellular spaces, collenchyma and parenchyma cortical tissues, parenchyma cells as pith tissues, absent of phloem strand in midrib while all the vascular bundle possess a crescent shape. (2a) TS of the midrib of Amaranthus hybridus Rivers South East with a rounded shape, an arc shaped vascular bundles arrangement, with four vascular bundles as well as the presence of trichomes. (2b) TS of the midrib of Amaranthus spinosus Rivers West with a crescent shape, while the vascular bundles arrangement also possess a crescent shape, absent of trichomes but protuberance or ridges and furrows were observed. (2c) Arc shape TS of the midrib of Amaranthus viridis Rivers East with an arch shape vascular bundles arrangement, possess six vascular bundles, absence of trichomes 
Table 1: Summary of important morphological features of the Amaranthus species studied

\begin{tabular}{|c|c|c|c|c|c|c|c|c|c|c|}
\hline $\mathrm{S} / \mathrm{N}$ & Characters & $\begin{array}{l}\text { TAXA } \\
\text { Rivers east } \\
\text { Aspinosus }\end{array}$ & $\begin{array}{l}\text { Rivers west } \\
\text { Aspinosus }\end{array}$ & $\begin{array}{l}\text { Rivers south } \\
\text { east } \\
\text { A.spinosus }\end{array}$ & $\begin{array}{l}\text { Rivers east } \\
\text { Anizidis }\end{array}$ & $\begin{array}{l}\text { Rivers west } \\
\text { Avividis }\end{array}$ & $\begin{array}{l}\text { Rivers south } \\
\text { east } \\
\text { Alividis }\end{array}$ & $\begin{array}{l}\text { Rivers east } \\
\text { A. hybuidus }\end{array}$ & $\begin{array}{l}\text { Rivers west } \\
\text { Ahwbidus }\end{array}$ & $\begin{array}{l}\text { Rivers south eas! } \\
\text { Alhwbridus }\end{array}$ \\
\hline 1 & Leaf shape & Qbovate & Qbovate & Qbovate & Qbovate & Qbovate & Qbovate & Ovate & Ovate & Ovate \\
\hline 2 & Leaf apex & Acute & Acute & Acute & Acute & Acute & Acute & Acute & Acute & Acute \\
\hline 3 & Leaf base & Suneate & Suneate & Suneate & Suneate & Suneate & Suneate & Suneate & $\begin{array}{l}\text { Broadly } \\
\text { cuneate }\end{array}$ & Suneate \\
\hline 4 & Margin & Entire & Entire & Entire & Entire & Entire & Entire & Entire & Entire & Entire \\
\hline 5 & Leaf size & $\begin{array}{l}\text { Up to } 7 \mathrm{~cm} \text { long and } \\
4.0 \mathrm{~cm} \text { broad }\end{array}$ & $\begin{array}{l}\text { Up to } 9 \mathrm{~cm} \text { long and } \\
4.0 \mathrm{~cm} \text { broad }\end{array}$ & $\begin{array}{l}\text { Up to } 9.4 \mathrm{~cm} \\
\text { long and } \\
4.5 \mathrm{~cm} \text { broad }\end{array}$ & $\begin{array}{l}\text { Up to } \\
10.0 \mathrm{~cm} \\
\text { long and } \\
5.5 \mathrm{~cm} \text { broad }\end{array}$ & $\begin{array}{l}\text { Up to } 20 \mathrm{~cm} \\
\text { long } \\
\text { and } 15 \mathrm{~cm} \\
\text { broad }\end{array}$ & $\begin{array}{l}\text { Up to } 11.5 \mathrm{~cm} \\
\text { long and } 6.3 \mathrm{~cm} \\
\text { broad }\end{array}$ & $\begin{array}{l}\text { Up to } \\
12.5 \mathrm{~cm} \\
\text { long and } \\
6.0 \mathrm{~cm} \text { broad }\end{array}$ & $\begin{array}{l}\text { Up to } 21.5 \mathrm{~cm} \\
\text { long } \\
\text { and } 15.0 \mathrm{~cm} \\
\text { broad }\end{array}$ & $\begin{array}{l}\text { Up to } 14.5 \mathrm{~cm} \\
\text { long and } 7 \mathrm{~cm} \text { broad }\end{array}$ \\
\hline 6 & Petiole length & Up to $7 \mathrm{~cm}$ long & $\begin{array}{l}\text { Up to } \\
5.1 \mathrm{~cm} \text { long }\end{array}$ & $\begin{array}{l}\text { Up to } 6.4 \mathrm{~cm} \\
\text { long }\end{array}$ & $\begin{array}{l}\text { Up to } 7 \mathrm{~cm} \\
\text { long }\end{array}$ & $\begin{array}{l}\text { Up to } 7.5 \mathrm{~cm} \\
\text { long }\end{array}$ & Up to $6.3 \mathrm{~cm}$ long & $\begin{array}{l}\text { Up to } 6.5 \mathrm{~cm} \\
\text { Long }\end{array}$ & $\begin{array}{l}\text { Up to } 8.0 \mathrm{~cm} \\
\text { Long }\end{array}$ & Up to $7.0 \mathrm{~cm}$ long \\
\hline 7 & Plant height & $90 \mathrm{~cm}$ long & $148 \mathrm{~cm}$ long & $1-40 \mathrm{~cm}$ long & $90.5 \mathrm{~cm}$ long & $152 \mathrm{~cm}$ long & $140 \mathrm{~cm}$ long & $80 \mathrm{~cm}$ long & $160 \mathrm{~cm}$ long & $104 \mathrm{~cm}$ long \\
\hline 8 & Phylotaxx & Altemate & Altemate & Altemate & Altemate & Altemate & Alternate & Altemate & Altemate & Altemate \\
\hline 9 & Stem color & Green & Reddish pink & Reddish pink & Reddish pink & Reddish pink & Reddish pink & Green & Green & Green \\
\hline 10 & Habitat & Wild & Wild & Wild & Wild & Wild & Wild & Cultivated & Wild & Cultivated \\
\hline 11 & Habit & Herb & Herb & Herb & Herb & Herb & Herb & Herb & Herb & Herb \\
\hline 12 & Venation & Reticulate & Reticulate & Reticulate & Reticulate & Reticulate & Reticulate & Reticulate & Reticulate & Reticulate \\
\hline
\end{tabular}

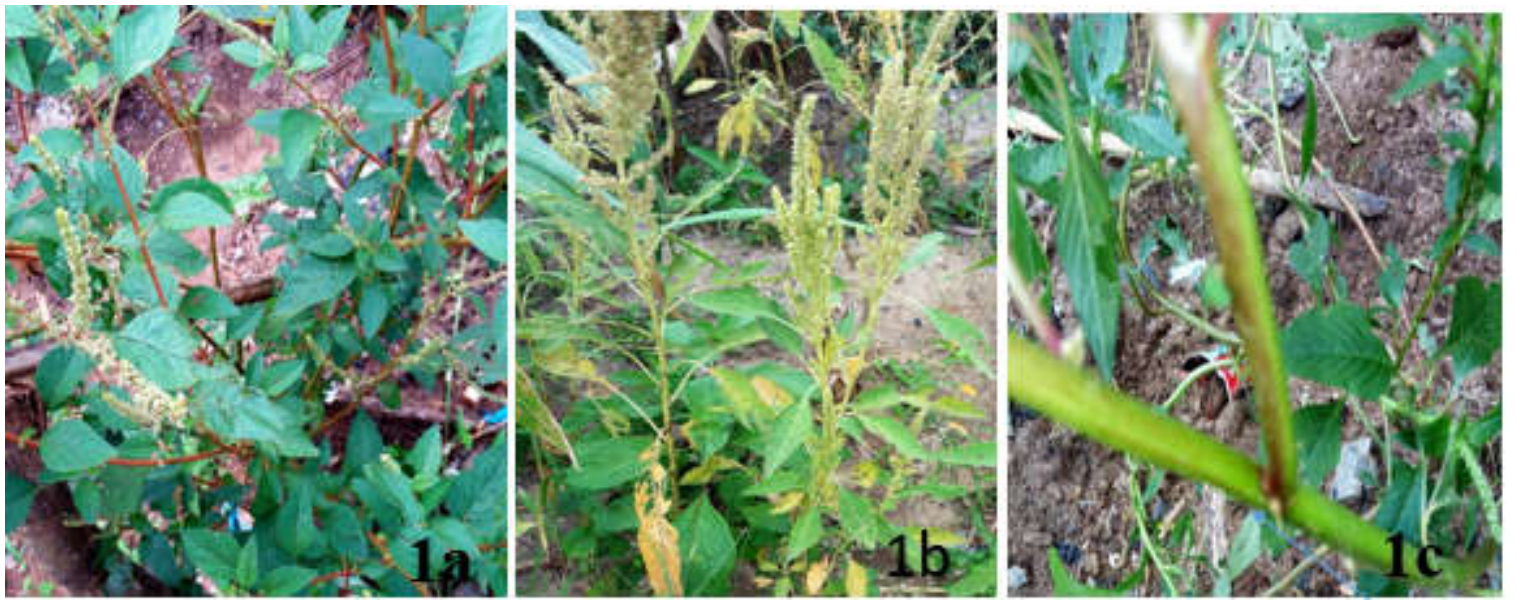

Plate 1a- 1c: (1a) Stand of Amaranthus viridis from Rivers West with obovate leaf shape, Cuneate leaf base with leaf size up to $20 \mathrm{~cm}$ long and $15 \mathrm{~cm}$ broad. (1b) Stand of Amaranthus hybridus from Rivers South East with Ovate leaf shape, Broadly cuneate leaf base and leaf size Up to $14.5 \mathrm{~cm}$ long and $7 \mathrm{~cm}$ broad (1c) Stand of Amaranthus spinosus from Rivers East showing the spine with alternate leaf phylotaxy with plant height up to $140 \mathrm{~cm}$ long. 
Petiole
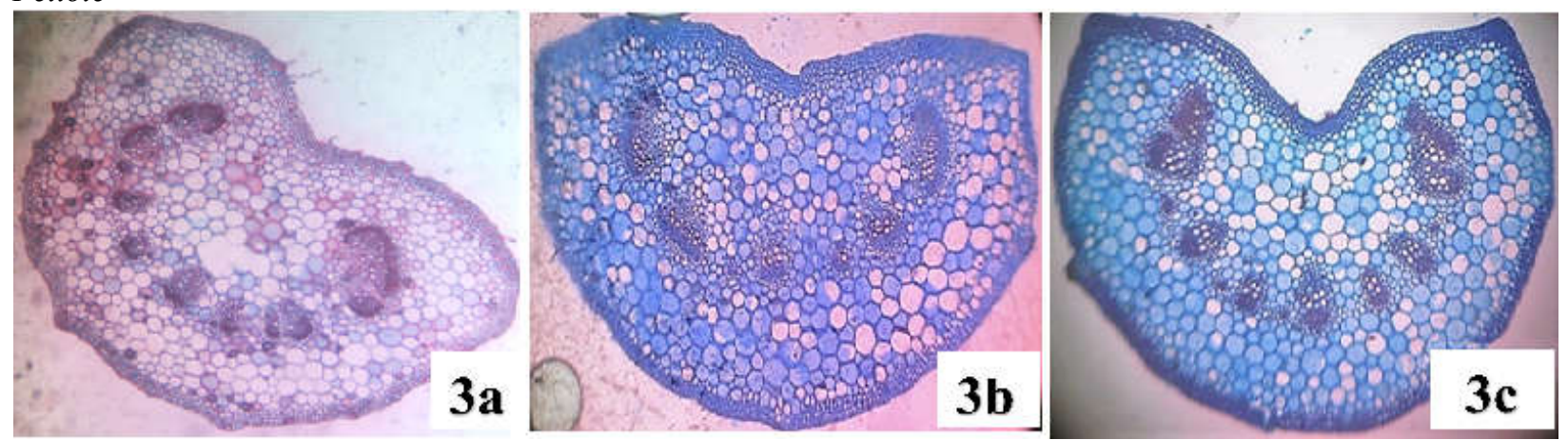

Plate 3a- 3c: All the species studied possess crescent as the shape of their vascular bundle arrangement, presence of sand crystals were observed as well as protuberance (3a) TS of the petiole of Amaranthus hybridus Rivers East with a cordate shape, vascular bundle arrangement has an arc shape, presence of trichomes is observed, while Vascular bundles observed were 9. (3b) TS of the petiole of Amaranthus spinosus Rivers West with a round shape, vascular bundle arrangement has a crescent shape, trichomes were not observed, while Vascular bundles observed were 7, (3c) TS of the petiole of Amaranthus viridis Rivers South East with a round shape, vascular bundle arrangement has an arc shape, trichomes were not observed, while Vascular bundles observed were 9.
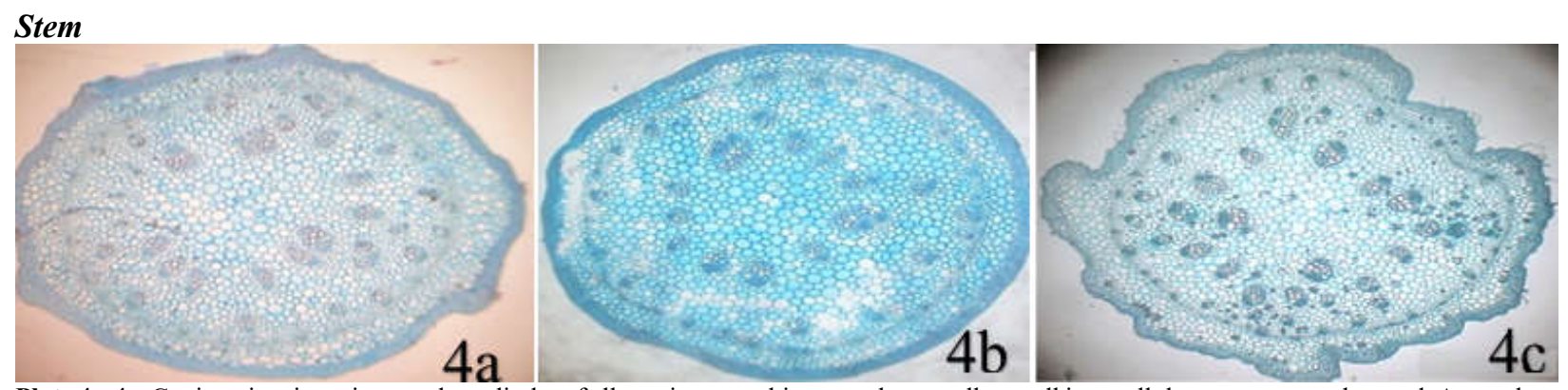

Plate 4a-4c: Conjugative tissue in vascular cylinder of all species were thin parenchyma cells, small intercellular spaces were observed, Anomalous cambial ring around the vascular cylinder was observed in all species (4a) TS of the stem of Amaranthus spinosus Rivers West possess irregular ovate shape, possess sand crystals, presence of angular epidermal circumference (4b) TS of the stem of Amaranthus viridis Rivers East possess rounded shape, absence of sand crystals, presence of round epidermal circumference (4c) TS of the stem of Amaranthus hybridus Rivers South East possess irregular ovate shape, presence of sand crystals, presence of angular epidermal circumference.

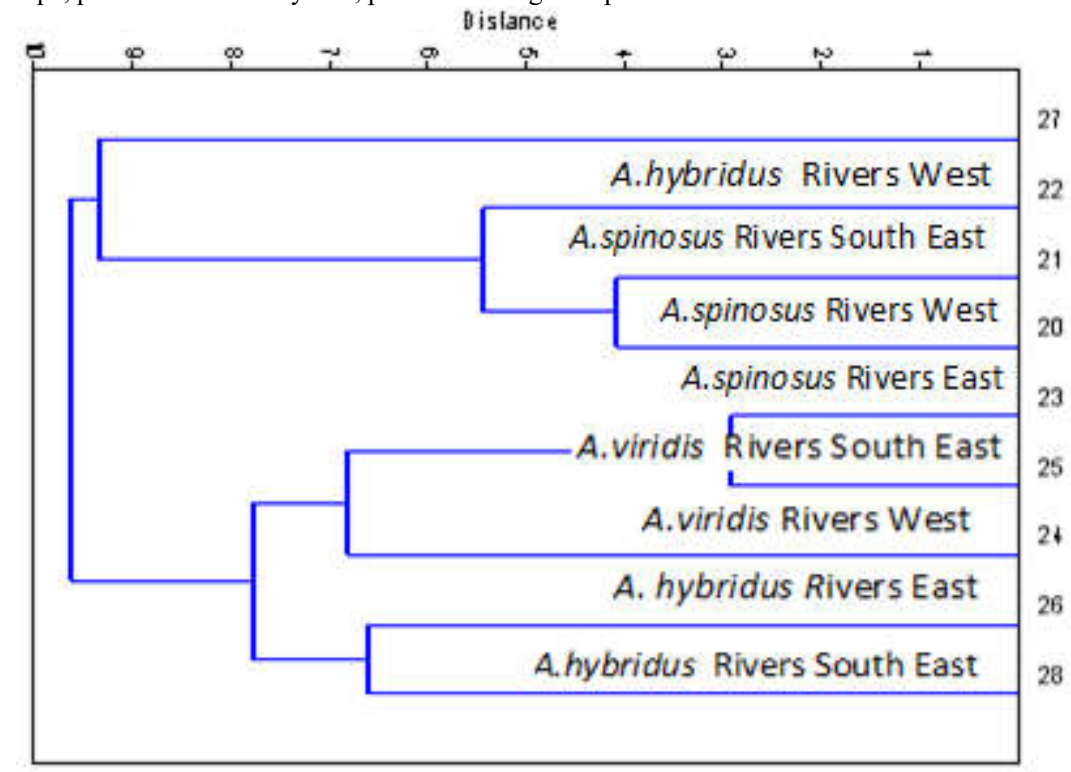

Fig 1: Dendogram of the nine Amaranthus species produced by cluster analysis using Past

Morphological study: Results gotten from qualitative characters like leaf apex, leaf base, habitat, habit, phyllotaxy, veination etc. were in conformity with
Hutchinson and Dalziel (1954), Burkill, (1985), Alege and Daudu (2014). The observation of spines in the three Amaranthus spinosus species studied from the three 
senatorial districts compared to absence of spines in others, are distinctive spot trait which obviously delineate the (3) Amaranthus spinosus species. Concerning quantitative characters the environment also have a major role as $A$. spinosus, $A$. hybridus and A.viridis from Rivers West a coastal region had the highest value for leaf size, petiole length and height followed by Rivers South East and lastly Rivers East.

Anatomical systematics: The noticeable character and thickness of epidermis of midrib, which was one layer in every species corroborated with Metcalfe and Chalk (1950) report in dicot. Variations were discovered in amount of vascular bundles in the midrib. Amaranthus hybridus, Rivers East has nine (9) vascular bundles, Rivers West six (6) vascular bundles and Rivers South East four (4) vascular bundles. For Amaranthus viridis, both Rivers East and Rivers South East possess six vascular bundles each while Rivers West A.viridis possess five vascular bundles. For Amaranthus spinosus studied Rivers East, Rivers West and Rivers South East A.spinosus possessed five, four and six vascular bundles respectively. Only A.hybridus and A. spinosus from Rivers South East with four and six numbers of vascular bundles respectively were compatible with the report of El-Ghamery et al. (2016). Result obtained from the petiole anatomy of $A$. spinosus and A.hybridus are compatible with the ones reported by El-Ghamery et al. (2016). While no study on $A$. viridis was found. Trichomes were reported to be absent in all species studied but only present in Amaranthus hybridus (plate 3a) from Rivers east, Protuberances was observed in all nine species studied. Variations also was observed in the amount of vascular bundles of petiole even among same species from different senatorial regions. Nine (9) vascular bundles were found in Amaranthus spinosus in Rivers East, Amaranthus viridis in Rivers East and Rivers South East and in Amaranthus hybridus in Rivers East and Rivers South East. Twelve (12) vascular bundles gotten in Amaranthus spinosus in Rivers South East, and Amaranthus viridis in Rivers West. Seven (7) and nineteen (19) vascular bundles were observed in Amaranthus spinosus and Amaranthus hybridus in Rivers West respectively. Only the result from Amaranthus spinosus from Rivers West with seven numbers of vascular bundles supported the report of ElGhamery et al. (2016) others varies and this variation is because Amaranthus species express high plasticity to ecological alterations and can easily adapt to diverse ecogeographical situations. The stem showed less variation between the studied species, although variations were again noticed in epidermal circumference of transverse section of stem. All features shown in the stem (internode) agreed with Metcalfe and Chalk (1950), Costea et al. (2001), Carlquist (2003), Kraehmer (2013),
Gaafar et al. (2015), and El-Ghamery et al. (2016) with little variations.

Numerical taxonomy: The dendogram produces three groups. The first group comprised just $A$. hybridus Rivers West, the second, all A.spinosus while the third consist of all A.viridis and A. hybridus from Rivers East and West. Amaranthus Spinosus Rivers East and Amaranthus spinosus Rivers West were observed to be similar species with slight variation as merge together at point 4.0 along the distance while Amaranthus spinosus South East although also cluster with them but at a further space of (5.5) showing elevated degree of variation. Amaranthus viridis demonstrated the slightest resemblance as $A$. viridis Rivers East and Rivers South East joined together at phenolic line 3.0 but also showed its diversity with $A$. viridis Rivers West branching out at a distant point of 7.0 along the distance linkage. Amaranthus hybridus recorded the utmost diversity as $A$. hybridus East and A. hybridus South East only join together at a distant point of 6.5 along the distance linkage meter while surprisingly A.hybridus West formed its own cluster group and even branched out early at 9.5 along the distance linkage.

Conclusion: The morphological and anatomical tests of the leaves, petiole and stems of the Amaranthus species served as systematic features in providing additional evidence, this research shows the high rate of variation that exist even among similar species growing in different eco-geographical regions. The dendogram constructed was able to show how Amaranthus species with adaptability to extensive eco-geographic regions, in their quest to express high plasticity to environment changes undergo series of variations in their Morphological and anatomical characteristics.

\section{REFERENCES}

Alege, GO; Daudu, SM (2014). A comparative foliar epidermal and morphological study of five species of the genus Amaranthus. European Journal of Experimental Biology, 4(4):1-8.

Bensch, EA (2003). Interference of redroot pigweed (A. retroflexus), Palmer amaranth (A.palmeri) and common waterhemp (A.rudis) in soybean. Weed Science, 51:37-43.

Blunden, G; Yang, M; Janicsak, G; Mathe, I; CarabotCuervo, A (1999). Betaine distribution in the Amaranthaceae. Biochemical Systematics and Ecology, 27:87-92.

Brenner, DM; Baltensperger, DD; Kulakow, PA; Lehmann, JW; Myers, RL; Slabbert, MM; Sleugh, 
BB (2000). Genetic Resources and breeding of Amaranthus (Vol. 19). (J. J, Ed.) wiley, USA: Plant Breeding Reviews.pp. 239-245

Burkill, HM (1985). The useful Plants of West Tropical Africa (2nd ed., Vol. 1). Kew, Richmond, United Kingdom: Royal Botanic Gardens. pp.120-129

Carlquist, S (2003). Wood and Stem anatomy of Woody Amaranthaceae ecology, systematics and problems of defining rays in dicotyledons. Botanical journal of Linnean society, 143:1-19.

Costea, M; Sanders, A; Waines, G (2001). Preliminary results towards a revision of the Amaranthus hybridus complex (Amaranthaceae). Sida, 19:931974.

El-Ghamery, AE (2017). Comparative anatomical studies on some species of the genus Amaranthus (Amaranthaceae) for the development of an identification guide. Annals of Agricultural Science.pp.123-129

Gaafar , A; Kasem, WT; Marei, H; El-Fadaly; Hanan Ghali. (2015). Morphological and stem anatomical description of 6 Amaranthus Species from Jazan, Saudi Arabia. International Journal of Current Research, 7:12277-12281.
Johansen, DA (1940). Plant Microtechnique. McGrawHill, New York, 523 pp.

Kraehmer, H (2013). Weed anatomy. A John Wiley \& Sons Ltd., Publication(Section 1) . pp. 34-37

Metcalfe, CR; Chalk, L (1950). Anatomy of the Dicotyledons (First edition ed., Vol. 2). Oxford: Clarendon Press. pp. 234-237

Mosyakin, SL; Robertson, KR (2003). Amaranthus: In Flora of North America. North of Mexico. New York,NY: Oxford University Press. pp. 126-128

Stallknecht, GF; Schulz-Schaeffer, JR (1993). Amaranth Rediscovered. In: Janick, J ; Simon, JE (Eds.) New crops Wiley New York, USA.pp. 19-25

Lee, JR; Hong, GY; Dixit, A; Chung, JW; Ma, KH; Lee, JH; Park, YJ (2008). Characterization of microsatellite Loci developed for Amaranthus Hypochondriacus and their cross-amplification in wild species. Conservation Genetics, 9:243-246. 